https://doi.org/10.48009/2_iis_2008_479-488

\title{
SIX SIGMA INFORMATION SYSTEMS: A PAYROLL APPLICATION
}

\author{
Roger L. Hayen, Central Michigan University, roger.hayen@cmich.edu
}

\begin{abstract}
This research examines the application of the Six Sigma methodology to a business problem that emerges with an information technology (IT) solution as the best alternative. A Time/Leave Reporting Process, which supports the payroll function, is investigated using Six Sigma methodology. This case application serves to demonstrate the Six Sigma approach to business process problem solving. One advantage of an IT solution is that control is instantiated that makes it very difficult to deviate from the new IT-based solution. Six Sigma and traditional IT business problem solutions share many techniques that are compatible with one another. Their synergies should undergo further examination to determine how these two methodologies can better support each other.
\end{abstract}

Keywords: Six sigma, systems development method, payroll system

\section{INTRODUCTION}

This research reports a case application of Six Sigma that happens to result in an IT solution. The project was initiated without any pre-disposed predilection of an IT solution. Six Sigma methodology provides a very robust tool set for addressing business problems or opportunities in order to formulate a best solution. The purpose here is not to review all the possible tools of Six Sigma methodology, but rather to show how a selected set of these tools are applied in addressing a business problem that happens to culminates in an IT solution. Here, the Six Sigma process itself leads to an IT solution as the preferred alternative. Six Sigma focuses on the process owner (the customer) by listening to the needs of that owner and then making improvements to the process [2]. A different project may apply other selected tools from among those used with Six Sigma projects. And, it could lead to a change in manual business processes rather than an automated solution.

Six Sigma projects take a problem approach to finding business solutions. That is, it is driven by the business problem first, rather than the availability of emerging IT. This is different from a more traditional IT approach that examines new and evolving technology and then searches for opportunities to deploy that technology. That is, the traditional IT approach is driven more by the availability of emerging technologies than business problems [13]. This represents a "push" arrangement wherein the technology solution is pushed by IT as an opportunity to address a business issue. On the other hand, Six Sigma is a "pull" process with the methodology identifying a potential IT application opportunity, whereby the business problem is examined by a team organized around the process owner, who is usually a business manager not otherwise associated with IT.

The characteristics and features of the Six Sigma methodology applied to IT development are examined using a published case-based research approach methodology. A case-based research approach provides a means for investigating phenomenon in information systems in their original context and is particularly appropriate for exploratory studies [15]. Applied to IT and Six Sigma, case-based research provides a schema for studying the characteristics of such applications. According to, Tsikriktsis and Frohlich [14] and Meredith [10], case-based research is one of the most powerful methods in the development of generalizable conclusions about a field of study. The results of case-based research can have a very high impact that leads to new and creative insights into a field of study with a high validity with practitioners - the ultimate user of research.

This case research examines an application at an educational institution. These organizations typically divide processes into academic and administrative. The administrative processes support the day-to-day activities of managing the institution. Opportunities exist for Six Sigma applications with academic processes [9]. The intangible nature of the educational process and product makes measurement vastly different from measuring the output of a process where physical properties with well established measurement procedures exist [1] The best areas for applying Six Sigma in educational institutions appear to be in nonacademic support areas [8]. This research focuses on that application with administrative processes.

The purpose of this research is to provide an example of how Six Sigma methodology can lead to an IT project and is used with such a project. The results 
are present as an overview of the Six Sigma process followed by the details of each phase of that process.

\section{SIX SIGMA METHODOLOGY}

The core of Six Sigma is relentless problem solving. Typically, the Six Sigma methodology is arranged as the five phase: define, measure, analyze, improve, control (DMAIC) [3]. These are the process phases utilized in this project.

- Define - Identify the project opportunities, select and prioritize projects, and draft the project charter.

- Measure - Identify the key internal process that influences the critical to quality (CTQ) characteristics.

- Analyze - Understand the root causes driving the defects. Brainstorming, prioritization, and statistical validation tools are used to identify the cause of defects.

- Improve - Confirm the key variables and then quantify the effect these variables have on the CTQs and make sure the measurement systems are capable of measuring process.

- Control - Ensure that the modified process enables key variables to stay within the acceptable ranges.

The Six Sigma project team consists of seven project roles assigned, in this case application, to six team members. For this project, these are black belt (intraining), green belt, process owner (same as green belt), local champion, financial representative, and master black belt. Black belts and green belts are team members with Six Sigma methodology training and provide support for carrying out that methodology. This project team interacts with other users as needed to conduct the project and obtain their input to the solution.

\section{DEFINE PHASE}

The define phase is summarized by the project charter for the Time/Leave Reporting Process (Figure 1). The charter results from several meetings with the project team. The project black belt, process owner, and local champion are the key team members who formulate the project chart. These meetings provide the means for identifying the business problem and revising it until the final version of the project charter results.

\section{MEASURE PHASE}

The measure phase focuses on several activities [4]. The current process is defined using process mapping and flowcharting tools. The defect is defined for the specific improvement opportunity. A measurement system or approach is determined and evaluated that reflects the business process. A data collection methodology is proposed and assessed. The process capability and sigma value calculations are carried out to establish a baseline for improvement. This lays the foundation for conducting data collection that is analyzed in the next phase.

\section{Process Map}

The process map develops an overview of the critical process (Figure 2). This assists in identifying inputs and outputs and in examining potential output measures. A "hidden factory" exists in many business processes. This is the result of process defects that must be corrected. When a defect occurs, first it must be found, and, second, action is required to remediate the defect. The correction activities are the hidden factory where additional work is required without adding value to the product or service. For the Time/Leave Reporting Process, this is the defect opportunity presented in the next section.

\section{Deployment Flowchart}

Details of the Time/Leave Reporting Process are analyzed using a deployment flowchart to portray the relationships among process steps or activities (Figure 3). The flowchart shows people/activities and departments responsible and their assigned process steps. This is very similar to process flowchart charts used in developing IT solutions. Those charts have a long history in IT analysis and design [11, p 127134]. They remain an important tool for understanding business processes within the Six Sigma methodology.

\section{Defect Opportunities}

A defect is the amount of labor time required in completing the Time/Leave Reporting Process with the cycle time as the amount of labor time required per employee paid. In this process, a voided item is an incorrectly issued pay check. These errors increase the cycle time. The current relative quantity of these errors should not be increased and are a constraint of this project. A measure of this constraint is calculated as follows: 
Voided item defect per opportunity (DPO) = Number of voided items from process errors / number of employees paid

This is a measure of the overall effectiveness of the process, where a defect is the process cycle time that is required to correct or rework a payroll entry in or- der to pay an employee. That is, a defect occurs with an error that must be corrected. The time to enter a value on a form is very short. Therefore, it is difficult to measure activity at this level. Hence, defect opportunities are combined for analysis, which simplifies data collection.

\section{Project Charter}

Project Impact/Strategic Alignment: Support the educational institution's academic mission by improving the time/leave reporting process.

Opportunity Statement: Current process is fragmented. Paper timesheets/time rosters require processing and handling by the initiating department and Payroll Services. Considerable time is used in finding and correcting error conditions that would result in a voided item (the issuance of an incorrect pay check).

Project Scope \& Boundaries: The paper-based time/leave reporting systems for all employee groups that encompasses the main campus and all satellite campuses.

Goal/Objectives: Developed an improved time/leave reporting process that is more efficient, reduces voided items, and meets the institution's reporting requirements.

Timeline: Completion of Control Phase by March 1.

Deliverables: Revised process to improve efficiency and reduce labor effort in reporting process. This should provide a soft dollar saving, which is still being determined. Documentation and training will be provided for a revised system. Other changes will be assessed at the end of the analyze phase.

Figure 1. Finalized Project Charter

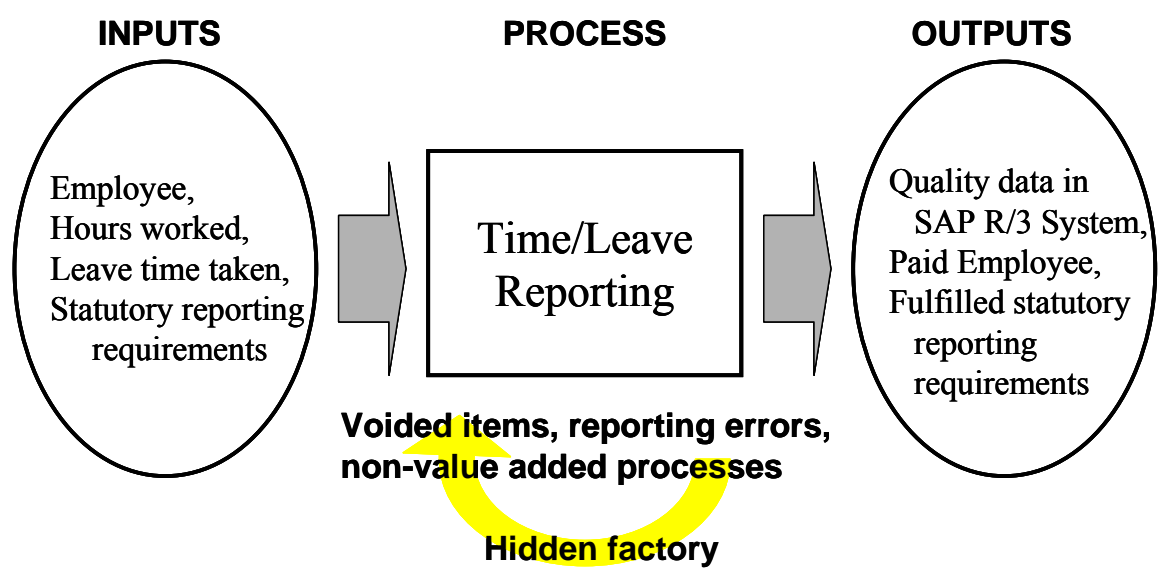

Figure 2. Process map

\section{Measurement Plan}

A good measurement system is needed to make correct decisions. While anything can be measured, it is important to concentrate on measurements that will lead to improving the business process. A good measurement system must be related to those activities which are critical to a process. They need to be reliable, easily understood, and have an identifiable variation. The measurement plan specifies what is to be measured, how it is to be measured and recorded, where it is measured and recorded, when it is to be measured and recorded, and who will do the measuring and recording. The method of measurement is proposed. The deliverable is the proposed method for conducting the data collection. A table layout is used to identify these performance measurement points. 


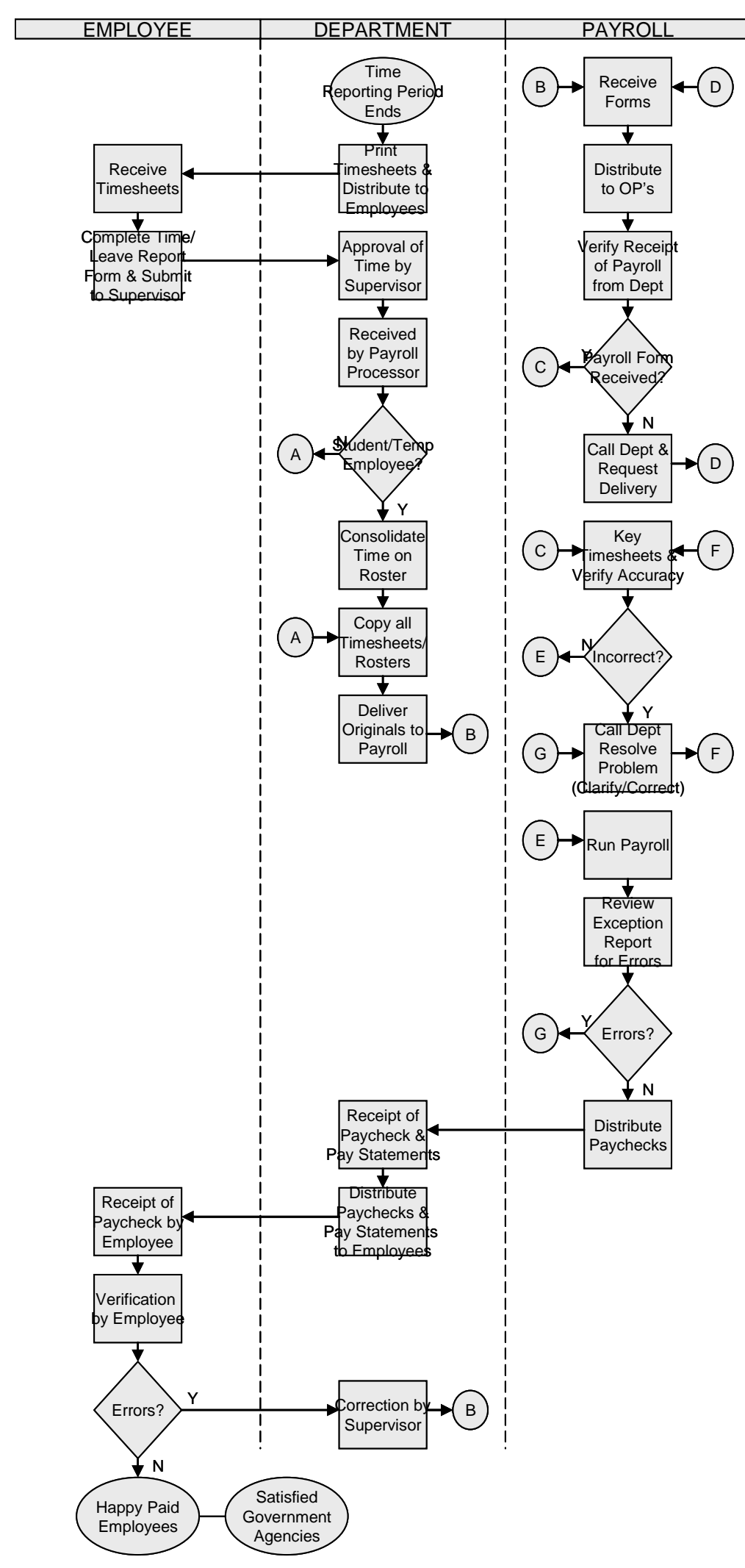

Figure 3. Time reporting process

\section{Root Cause Evaluation}

Root cause evaluation looks at the apparent problems and their possible root cause. These possible root causes identify key variables for which data need to be collected. A subjective, weighted analysis is done to provide an indication of the ability to collect this data (Table 1).

\section{Sigma Value}

Process capability is concerned with measuring the quality of the current process compared to some target. In a Six Sigma project, it is important to express the performance of the current process, which is being examined. The key question addressed is the determination of whether the current process is capable of meeting customer requirements. The sigma value, defects per million occurrences (DPMO), and capability value (Cpk) are measures of process capability. The sigma value is a quality level. This is related to the calculated standard deviation of the data; however, that standard deviation is only an input to a formula that is then used to calculate the long-term capability in the Improve phase. Six-sigma performance produces 1 defect per billion opportunities, over the short term.

Recall that the overall error rate, as measured in voided items, is not to increase as a result of any changes in the Time/Leave Reporting Process revision. The current number of voided items per million employee payments is 2,200. That is, the defects per million opportunities (DPMO) is 2,200. This translates to a $\sigma$-value of 4.35 , which is less than the target level value of 6.00 . This constraint is not to have any decrease as a result of process improvements.

However, a small number of voided items could still be very time consuming in making the needed corrections. As a result, the cycle time is judged to be a better measure of the defect. For cycle time the DPMO is 289,000 , which translates to a $\sigma$-value of 2.06 . 
That is, this is the number of items where the cycle time is greater than the theoretical limit. This provides a focus on the cycle time as a key process ac- tivity that is to be addressed through this Six Sigma project.

Table 1. Root Cause Evaluation Chart

\begin{tabular}{|c|c|c|c|c|c|}
\hline Problem/Error Type & Pocciblo Pontrauce & & & & \\
\hline \multirow{5}{*}{ Missing Data } & & & & I Tlal & \\
\hline & Employee forgot to fill out timesheet & 3 & 3 & 6 & $\begin{array}{l}\text { Yes, by count of } \\
\text { missing timesheets }\end{array}$ \\
\hline & $\begin{array}{l}\text { Supervisor's don't collect the time reports } \\
\text { (aren't very responsible) }\end{array}$ & 1 & 1 & 2 & $\begin{array}{l}\text { Yes, by having the } \\
\text { departments count } \\
\text { missing timesheets }\end{array}$ \\
\hline & $\begin{array}{l}\text { Supervisor is on vacation or out sick and } \\
\text { responsibility of collecting reports has not } \\
\text { been delegated }\end{array}$ & 1 & 1 & 2 & $\begin{array}{l}\text { Yes, by having the } \\
\text { departments count. }\end{array}$ \\
\hline & $\begin{array}{l}\text { Payroll processor is on vacation or out sick } \\
\text { and responsibility of collecting reports has } \\
\text { not been delegated }\end{array}$ & 1 & 1 & 2 & $\begin{array}{l}\text { Yes, by having the } \\
\text { departments count. }\end{array}$ \\
\hline \multirow[t]{7}{*}{ Errors in Data Collected } & $\begin{array}{l}\text { Employees, supervisors or payroll } \\
\text { processors do not know employee } \\
\text { contracts or policies }\end{array}$ & 3 & 9 & 12 & $\begin{array}{l}\text { Yes, by counting } \\
\text { each time we have } \\
\text { to explain the } \\
\text { contract }\end{array}$ \\
\hline & $\begin{array}{l}\text { There is limited training for employees and } \\
\text { supervisors on how to fill out the time } \\
\text { report }\end{array}$ & 9 & 9 & 18 & $\begin{array}{l}\text { No, not sure how } \\
\text { we would, unless } \\
\text { new EE's }\end{array}$ \\
\hline & $\begin{array}{l}\text { There are human errors when transferring } \\
\text { data from one time report to another }\end{array}$ & 3 & 9 & 12 & $\begin{array}{l}\text { Yes, by counting } \\
\text { post payroll errors }\end{array}$ \\
\hline & $\begin{array}{l}\text { The hiring data for the employee has not } \\
\text { been entered into the SAP system \& } \\
\text { therefore does not display on the time } \\
\text { report }\end{array}$ & & 1 & 1 & $\begin{array}{l}\text { Yes, by counting } \\
\text { calls we make to } \\
\text { employment offices }\end{array}$ \\
\hline & $\begin{array}{l}\text { Paperwork has not been processed for } \\
\text { changes to pay or cost centers through HR } \\
\text { resulting in incorrect data on time report }\end{array}$ & 1 & 1 & 2 & $\begin{array}{l}\text { Yes, but difficult, } \\
\text { would take a lot of } \\
\text { inquiry }\end{array}$ \\
\hline & $\begin{array}{l}\text { Financial aid package changes after time } \\
\text { report is printed, therefore incorrect data } \\
\text { displays on time report }\end{array}$ & 3 & 1 & 4 & $\begin{array}{l}\text { Yes, but difficult, } \\
\text { would take a lot of } \\
\text { inquiry }\end{array}$ \\
\hline & $\begin{array}{l}\text { Employees try to circumvent the system } \\
\text { and intentionally enter incorrect data } \\
\text { because they disagree with policy or are } \\
\text { dishonest }\end{array}$ & 1 & 1 & 2 & No \\
\hline Keying Errors & $\begin{array}{l}\text { There are human errors when keying or } \\
\text { interpreting data from time reports }\end{array}$ & 1 & 9 & 10 & $\begin{array}{l}\text { Yes, by counting } \\
\text { post payroll errors } \\
\text { of this category }\end{array}$ \\
\hline \multicolumn{2}{|c|}{ Probability of occurrence (frequency) \& Actionable Ratings: } & & & & \\
\hline \multicolumn{2}{|c|}{ High $=9$, Medium $=3$, Low $=1$} & & & & \\
\hline
\end{tabular}

\section{ANALYZE PHASE}

The purpose of the analyze phase [5] is to establish a relationship between the defect and the variables that control it. Data are used to explore and statistically validate the relationship between the root cause and the defect. Cycle time reduction (CTR) tools support the analysis of the time and cost/investment of the 
process. CTR provides an understanding of the inefficiencies or waste identification and elimination. With CTR, value adding process steps are identified in evaluating process efficiency. The key question in CTR is "Does this step add value to the process?' A non-value added activity is one that is not essential for meeting requirements. Some team members felt that keying data written on a form was a value-adding step. An explanation clarified how keying data, which is already captured, is not a value-added activity. Value-added activities provide a focus for the root cause addressed by the Six Sigma project.

\section{$\mathbf{A} \Delta \mathbf{T}$}

The $\mathrm{A} \Delta \mathrm{T}$ (A delta $\mathrm{T}$ ) technique is used for calculating the non-value adding process time. Then the root causes for non-value adding time undergo further examination for process improvement.

The A $\Delta \mathrm{T}$ measure is calculated as follow:

$\mathrm{A} \Delta \mathrm{T}$ ratio $=$ Actual (time) $/$ Theoretical (time)

Where Theoretical (time) $=$ Value Added - Actual (time) $=$ Theoretical (time) $+\Delta$ (time)

And $\Delta($ time $)=$ Non-value Added (time) in-

cluding Rework (time)

$\mathrm{A} \Delta \mathrm{T}$ for the payroll processing time is calculated as 3.84. That is, the actual time is nearly four times the theoretical time. Or, nearly 75 percent of the actual time is consumed by non-value added processes. These non-value added processes are candidates for elimination in making changes.

\section{Cost-Time Profile Analysis}

Some Six Sigma projects focus on CTR. While reducing costs improves operating profit and reduces cash requirements, reducing cycle time improves customer service, quality, and cash flow. Gathering data for the cycle time portion of a cost-time profit analysis is often easier than obtaining the cost information. Cycle time supports concentrating on those process steps that add the most value to the project. Non-value added cycle time steps emerge as candidates for elimination.

The deployment flowchart (Figure 3) furnishes the framework for the process steps that are measured and analyzed (Figure 4). The amount of labor time to pay one employee is determined to be 5.3 minutes. Of this time, 3.9 minutes is non-value added time, so the value added time is 1.4 minutes. As indicated in Figure 4, both the non-value added employee time and the number of processing steps is 74 percent of these processes to pay one employee. So, the value added time and steps is 26 percent. This is a coinci- dental result, which is not likely to occur frequently in other similar project. The non-value added time per employee pay extrapolates to about 9,000 hours per year or roughly 4 full-time equivalent (FTE) employees. Elimination of these non-value added process activities represent an approximate labor savings of $\$ 30,000$ per year in direct savings and $\$ 150,000$ in soft or indirect saving.

\section{IMPROVE PHASE}

Six Sigma focuses on the inputs and processes that create output of interests to either internal or external customers [6]. The variation inherent in these outputs is determined by the variation in each of the independent variables of the processes and inputs. The purpose of the Improve phase is to determine a set of activities that enable the optimization of a process so that a required level of performance is delivered as defined by the customers of the process. In this phase, alternative solutions are identified, and the "best" or "optimal" solution is selected from among those alternatives. Brainstorming is used to generate a maximum number of ideas. The opportunity statement is the foundation for brainstorming. Idea generation goes beyond the immediate Six Sigma project team and involves many other participants in the process being examined. The ideas from brainstorming are organized and evaluated as the best solution is selected.

\section{Opportunity Statement}

The opportunity statement sets the stage for brainstorming. This is the focus of all the ideas which are generated. For the Time/Leave Reporting Process this statement for an improved solution with reduced cycle time is:

"How might we reduce the amount of personnel time used in performing the payroll Time/Leave Reporting Process for hourly and salary employees?"

\section{Brainstorming Morphological Box}

Brainstorming generates many ideas which are organized by affinitization. Brainstorming employs a variety of tools [6] to produce a large idea pool. These include pattern breaking tools, the idea mover, forcing associations, reversing assumptions, making comparisons, other points of view, and outrageous ideas. Once the pool is generated, then ideas are affinitized by organizing like ideas together in related categories. Those categories of ideas are subsequently grouped together to build an alternative solution. The categories and each of the alternative solu- 
tions are summarized in a morphological box (Figure 5). Two alternative solutions emerged. One is maximum automation. The second is to automate collection. Both of these are IT solutions, as opposed to changes or modifications in manual processes. No alternative solutions were found that provide a best solution by only changes to manual processes. Clearly, the proposed alternatives surfaced as a natural consequence of the Six Sigma methodology. They were a pull recommendation and not a push solution recommend from IT for deploying new, emerging technology. The maximum automation solution encompassed all nine solution categories, whereas the automate collection consists of only four categories or subheadings. The evaluation criteria are applied to each of these identified solutions using a nominal weighting scheme. These values are then summed to identify the best alternative. With a score of 36 this is the automate collection solution. The lower level elements of the categories, the brainstorm ideas, are shown in Figure 6. An optimal solution is available for further consideration.

\begin{tabular}{|c|c|c|c|c|c|}
\hline Actual Process Step & $\begin{array}{l}\text { Time (per } \\
\text { employee) } \\
\text { (minutes) }\end{array}$ & $\begin{array}{c}\text { Time (per } \\
\text { Payroll) } \\
\text { (minutes) }\end{array}$ & $\begin{array}{l}\text { VA } \\
\text { (Y or } \\
\text { N) }\end{array}$ & & $\begin{array}{c}\text { Number } \\
\text { Employees } \\
\text { (avg } \\
\text { payroll) }\end{array}$ \\
\hline Receive Timesheets & 0.0333 & 176.0 & $\bar{Y}$ & & 5286 \\
\hline Complete Time/Leave Report Form \& Submit to Supervisor & 1.0000 & 5286.0 & $\bar{Y}$ & & 5286 \\
\hline Print Timesheets \& Distribute to Employees & 0.0536 & 283.5 & $\mathrm{~N}$ & & 5286 \\
\hline Approval of Time by Supervisor & 0.2500 & 1321.5 & $\bar{Y}$ & & 5286 \\
\hline Received by Payroll Processor & 0.0333 & 176.0 & $\mathrm{~N}$ & & 5286 \\
\hline Consolidate Time on Roster & 1.9084 & 10087.9 & $\mathrm{~N}$ & & 5286 \\
\hline Correction during Consolidate & 0.6566 & 3470.7 & $\mathrm{~N}$ & & 5286 \\
\hline Copy all Timesheets/Rosters & 0.0119 & 63.0 & $\mathrm{~N}$ & & 5286 \\
\hline Deliver Originals to Payroll & 0.4291 & 2268.0 & $\mathrm{~N}$ & & 5286 \\
\hline Receive Forms (in Payroll) & 0.0333 & 176.0 & $\mathrm{~N}$ & & 5286 \\
\hline Distribute to OP's & 0.0800 & 422.9 & $\mathrm{~N}$ & & 5286 \\
\hline Verify Receipt of Payroll from Dept & 0.0333 & 176.0 & $\mathrm{~N}$ & & 5286 \\
\hline Call Department \& Request Delivery & 0.0238 & 126.0 & $\mathrm{~N}$ & & 5286 \\
\hline Key Timesheets \& Verify Accuracy & 0.4107 & 2171.0 & $\mathrm{~N}$ & & 5286 \\
\hline Call Dept Resolve Problems (Clarify/Correct) & 0.0366 & 193.5 & $\mathrm{~N}$ & & 5286 \\
\hline Run Payroll (Total pay 3-5 hrs., off cycle indiv. Pay $1.5 \mathrm{~min}$.) & 0.0341 & 180.3 & $\mathrm{Y}$ & & 5286 \\
\hline Review Exception Report for Errors & 0.0168 & 88.8 & $\mathrm{~N}$ & & 5286 \\
\hline $\begin{array}{l}\text { Distribute Paychecks (to Dept) (Entire campus by Delivery } \\
\text { dept.) }\end{array}$ & 0.0397 & 240.0 & $\mathrm{~N}$ & & 5286 \\
\hline Receipt of Paycheck \& Pay Statements (in Dept) & 0.0333 & 176.0 & $\mathrm{~N}$ & & 5286 \\
\hline Distribute Paychecks \& Pay Statements to Employees & 0.0333 & 176.0 & $\mathrm{Y}$ & & 5286 \\
\hline Receipt of Paycheck by Employee & 0.0333 & 176.0 & $\bar{Y}$ & & 5286 \\
\hline Verification by Employee & 0.0333 & 176.0 & $\mathrm{~N}$ & & 5286 \\
\hline Correction by Supervisor (if Error) & 0.0978 & 517.0 & $\mathrm{~N}$ & & 5286 \\
\hline & & & & & \\
\hline Total & 5.3156 & 28128.2 & & & \\
\hline Value Added processes & 1.3840 & 7315.8 & 6 & $26.01 \%$ & $26.09 \%$ \\
\hline Non-value Added processes & 3.9316 & 20812.3 & 17 & $73.99 \%$ & $73.91 \%$ \\
\hline
\end{tabular}

Figure 4. Processing time per employee

\section{Risk/Benefit Analysis}

Project objectives are threatened by many potential problems. Risk analysis identifies problems and proposes actions that will minimize or eliminate their impact on a project. Benefit analysis looks at the other side of the project at activities that will maximize the quality of the project, so these actions can be supported in conducting the projects. The activities of the risk/benefit analysis have costs and expected gains associated with them. The risk/benefit analysis (Figures 7) details these actions, and their expected monetary results for guiding the Six Sigma project's implementation.
Comparing benefits to costs, the one-time costs of the project are expected to be recovered in 2.4 years. This payback makes this a feasible project, which supports proceeding with its implementation.

\section{Implementation "Speed Bump"}

A "speed bump" is a challenge that interrupts an implementation. For this project, it results in shifting this from a Six Sigma project to an IT project for the procurement and installation of the selected software solution. Once remediation is determined to be a software solution, then the Six Sigma project inter- 
faces with an IT project. That is, the actual acquisition and installation of the software solution requires requesting IT resources for implementation. Until this point in the project, control of the project is with the Six Sigma project team. When the software implementation shifts to the IT staff as one of their projects, then resources are allocated and tasked for that implementation. Project control shifts to the IT services organization. This is not the usual manner in which a typical Six Sigma project is expected to be conducted, wherein the Six Sigma team controls the resources, end-to-end, required for the entire process including implementation. However, a speed bump is a reality of a Six Sigma project, especially, where the best solution appears as computer automation.
This was a lesson learned with this project, which was not set out as a Six Sigma project occurrence during the Six Sigma black belt training. In training, the entire project is under the control of the project team. Had the solution manifest itself as revisions to a manual process, which it could have, then this speed bump impediment would not occur in the Six Sigma project. Based on this application case, these speed bumps become part of project implementation whenever the control of implementation resources falls outside the direct management scope of the project team. Speed bumps are a reality of Six Sigma projects and must be anticipated by the process owner and other project team members.

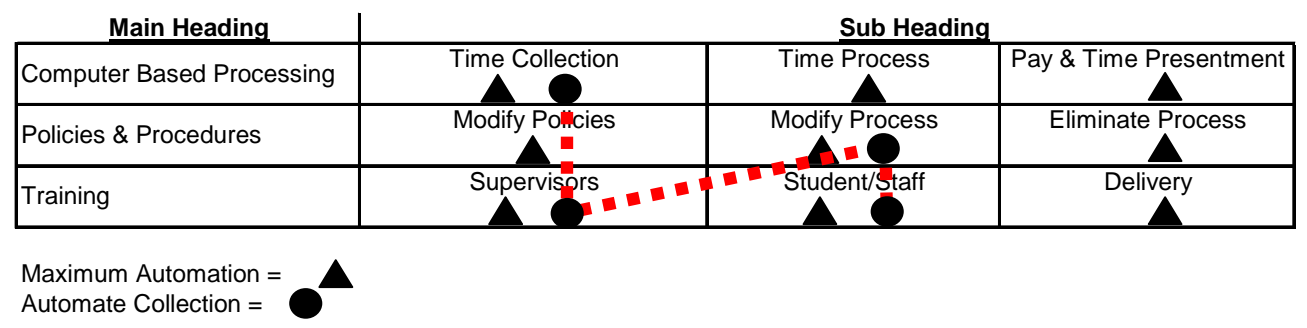

Evaluation Criteria

\begin{tabular}{|l|c|c|c|c|c|c|c|}
\hline & $\begin{array}{c}\text { Overall } \\
\text { Commitment }\end{array}$ & $\begin{array}{c}\text { Benefits } \\
\text { (Outcome) }\end{array}$ & Time frame & Policy/ Legal & Costs & $\begin{array}{c}\text { Controlled } \\
\text { Process }\end{array}$ & $\begin{array}{c}\text { Total } \\
\text { Tromaluation Criteria }\end{array}$ \\
\hline Maximum Auotmation = & 9 & 9 & 1 & 3 & 1 & 9 & 32 \\
\hline Automate Collection $=$ & 9 & 9 & 3 & 9 & 3 & 3 & 36 \\
\hline
\end{tabular}

Figure 5. Brainstorming Morphological Box

\begin{tabular}{|c|c|c|c|c|c|c|}
\hline \multirow[t]{3}{*}{ Solution Name } & Subheads & \multicolumn{3}{|c|}{ Supporting Ideas --> } & & \\
\hline & \begin{tabular}{|l} 
Time \\
Collection
\end{tabular} & Time Clocks & $\begin{array}{l}\text { EE's enter own } \\
\text { time on web } \\
\text { based system }\end{array}$ & $\begin{array}{l}\text { Workflow -- } \\
\text { SAP }\end{array}$ & & \\
\hline & \begin{tabular}{|l} 
Modify \\
Process
\end{tabular} & \begin{tabular}{|l} 
Everyone is \\
negative pay \\
except \\
students and \\
temps are on \\
Timelink
\end{tabular} & $\begin{array}{l}\text { Don't require } \\
\text { employees to } \\
\text { sign timesheet }\end{array}$ & & & \\
\hline \multicolumn{7}{|l|}{\begin{tabular}{|l|} 
Automate \\
Collection \\
Web-based \& \\
SAP Direct
\end{tabular}} \\
\hline & \begin{tabular}{|l} 
Eliminate \\
Process
\end{tabular} & \begin{tabular}{|l|} 
Remove \\
consolidation \\
of time on \\
roster -Enter \\
time directly on \\
roster
\end{tabular} & $\begin{array}{l}\text { Call } \\
\text { departments to } \\
\text { request } \\
\text { delivery - save } \\
\text { time }\end{array}$ & $\begin{array}{l}\text { Do not call } \\
\text { depts. with } \\
\text { errors }\end{array}$ & $\begin{array}{l}\text { No additions } \\
\text { once payroll is } \\
\text { submitted to } \\
\text { payroll }\end{array}$ & $\begin{array}{l}\text { Corrections on } \\
\text { next PR only } \\
\text { (no voids } \\
\text { additions) no } \\
\text { off cycle }\end{array}$ \\
\hline & $\begin{array}{l}\text { Supervisor } \\
\text { Training }\end{array}$ & $\begin{array}{l}\text { Supervisor } \\
\text { training for } \\
\text { completing } \\
\text { EE's time }\end{array}$ & $\begin{array}{l}\text { Train dept. on } \\
\text { The virtues of } \\
\text { Timelink }\end{array}$ & $\begin{array}{l}\text { Training on } \\
\text { payroll } \\
\text { calendar } \\
\text { deadlines }\end{array}$ & & \\
\hline
\end{tabular}

Figure 6. Selected Optimal Solution 


\begin{tabular}{|c|c|c|c|}
\hline Benefits & Actions to Maximize & $\begin{array}{l}\text { Benefts } \\
\text { One-Time }\end{array}$ & $\begin{array}{l}\text { Benefits } \\
\text { On-Going }\end{array}$ \\
\hline $\begin{array}{l}\text { Would eliminate } 99 \% \text { of duplicate data } \\
\text { entry if employees enter time directly } \\
\text { vs. employee entering on T/S and then } \\
\text { payroll entering into SAP. [This is a } \\
\text { portion of the soft savings sited below] }\end{array}$ & & & $\$ 12,323$ \\
\hline $\begin{array}{l}\text { Eliminates duplication of data entry by } \\
\text { departments for student employees - } \\
\text { no longer will need to transfer detailed } \\
\text { data to timesheet roster. [This is a } \\
\text { portion of the soft savings sited below] }\end{array}$ & $\begin{array}{l}\text { Improve training for employees and } \\
\text { departments }\end{array}$ & & $\$ 39,607$ \\
\hline & & & \\
\hline $\begin{array}{l}\text { Eliminate duplication of data entry in } \\
\text { centralized payroll offices, this should } \\
\text { eliminate approximately } 1 / 2 \text { an FTE }\end{array}$ & & & $\$ 28,280$ \\
\hline \$ Impact: & & $\$ 0$ & $\$ 80,493$ \\
\hline
\end{tabular}

Figure 7. Risks/benefits analysis chart - Benefits

\section{Selected IT Solution}

TimeLink [12] was the IT solution selected by the process owner and IT staff using IT's methods for the evaluation, selection, and contracting for this software. TimeLink is a web-based solution that interfaces with the SAP R/3 Enterprise Software that handles the payroll processing within the human relations (HR) application module. This is the same HR module that does the entire payroll processing that produces employee paychecks for the educational institution.

TimeLink Enterprise 6 is a comprehensive family of workforce management solutions, providing a fully integrated set of industry leading applications to optimize the productivity of an organization's most valuable asset - its people. The solution set includes:

- Time and Attendance

- Workforce Scheduling

- Employee Self-Service

- Reporting and Analytics

As a pure internet application, TimeLink has an open architecture and a library of pre-built interfaces with leading ERP, HR and Payroll systems serves to leverage existing investment in technology systems and infrastructure.

An earlier release of the TimeLink software was previously installed by the education institution to han- dle some of their time clock data collection for payroll. However, TimeLink was not deployed to all hourly paid employees. The Six Sigma methodology guided the solution to IT's selection method that, in turn, placed TimeLink on the table as one of the possible IT solutions that were evaluated. Considering both the prior experience and the functional features of TimeLink, the IT department and the process owner evaluated it as the best software meeting their processing requirements. Without making this a Six Sigma project, this may have been a solution that would have eventually been explored for improving the payroll process. However, with the Six Sigma approach, the non-value added steps and their related data were clearly determined and analyzed in searching for an improved solution. This clearly differentiated this Six Sigma approach to the project from more traditional approaches to IT projects.

\section{CONTROL PHASE}

The purpose of the control phase [7] is to ensure the improved process performance is maintained over the long term, key learning is documented and shared, and the results are validated. Sustaining the gains means that changes/improvements are successfully implemented and stay implemented forever. Here, forever is defined as that time until there is a significant change in the business process. Sustainability does mean considering foreseeable future events that 
could threaten the improved process. This includes changes in volume, personnel and customer expectations.

When the implemented solution is an IT solution, the chance or risk of reverting back to the old manual processes are minimized. This is different from when changes are often made to manual processes. With manual process changes, increased diligence is required to insure that employees do not cross the line and return to the old ways. An IT solution removes the old way, like burning a bridge. It becomes very difficulty to return to the old manual processes. As an IT solution, the manual processes of the internal factory have been eliminated. Data are entered directly by the employee and flow through the IT solution into the payroll system. Hence the non-value added process steps no longer exist in the business process. Employees cannot use the old manual system with all the non-value added step. In this manner, the IT solution brings a discipline to the Time/Leave Payroll Process that simply must be followed for an employee to receive a paycheck. The process owner has a solution, which insures sustainable gains.

\section{CONCLUSION}

This research effort examined the use of the Six Sigma methodology in providing an IT solution to a business problem. The Time/Leave Reporting Process was observed in applying this methodology to that business problem. Six Sigma is a pull process that is driven by a project team organized around a process owner and conducted with the assistance of a Six Sigma black belt. Following the data-driven, five-phased approach of Six Sigma, an IT solution emerged as the best method for mitigating the business problem with an improved process. An IT solution instantiates a robust control arrangement, because it removes old ways of carrying out these business processes. This elimination, or "burning bridges," insures the continuation of the new process until there is a change in how business is conducted.

The Six Sigma methodology shares a number of problem solving techniques and methods with prior approaches to IT problem solving. However, Six Sigma is more business problem centric with the process driven by a business area team, rather than an IT project team. Six Sigma and traditional IT project methods appear to be compatible. Both Six Sigma project teams and IT project teams can learn from each other as their methodologies continue to evolve.
That is, these methods are complimentary and not mutually exclusive. Future research should examine additional Six Sigma projects that result in IT solutions to illuminate the synergy among the techniques of these business problem solving approaches.

\section{REFERENCES}

1. Does, R. J., Van den Heuvel, E. R., De Mast, J., \& Bisgaard, S. (2002). Comparing non-manufacturing with traditional applications of six sigma. Quality Engineering, 15(1), 177-182.

2. Douglas, P. C., \& Erwin, J. (2000). Six sigma's focus on total customer satisfaction. The Journal of Quality and Participation, 23(2), 45.

3. Dow. (2003). Dow Six Sigma black belt certification - Orientation. Midland, MI: The Dow Chemical Company.

4. Dow. (2004). Dow Six Sigma black belt certification - Measure. Midland, MI: The Dow Chemical Company.

5. Dow. (2004). Dow Six Sigma black belt certification - Analyze. Midland, MI: The Dow Chemical Company.

6. Dow. (2004). Dow Six Sigma black belt certification - Improve. Midland, MI: The Dow Chemical Company.

7. Dow. (2004). Dow Six Sigma black belt certification - Control. Midland, MI: The Dow Chemical Company.

8. Gross, J. M. (2001). A road map to six sigma. Quality Progress, 34(11), 28-29.

9. Holmes, M. C., Kumar, A., \& Jenicke, L. (2005). Improving the effectiveness of the academic delivery process utilizing Six Sigma. Issues in Information Systems, 6(1), 353-359.

10. Meredith, J. (1998). Building operations management theory through case and field research. Journal of Operations Management, 16, 441-454.

11. Semprevivo, P. C. (1976). Systems analysis: Definition, process, and design. Chicago: SRA.

12. TimeLink, (2005, January). TimeLink Enterprise 6. Larchmont, NY: Author.

13. Vitt, E., Luckevich, M., \& Misner, S. (2002). Business intelligence: Making better decision faster. Redmond, WA: Microsoft Corporation.

14. Voss, C., Tsikriktiss, N., \& Frolich, M. (2002). Case research in operations management. International Journal of Operations \& Management, 22(2), 195-219.

15. Yin, R. K. (1993). Applications of case study research. Newbury Park, CA: Sage Publications. 